\title{
Improving the technology of cooked sausages using protein-mineral-hydrocarbon additive
}

\section{Lyudmyla Peshuk, Oleksandr Gorbach, Oleg Galenko}

\author{
National University of Food Technologies, Kyiv, Ukraine
}

\begin{tabular}{|c|c|}
\hline & Abstract \\
\hline Keywords: & Introduction. Studies have been conducted to determine the \\
\hline Protein & effect of adding chitosan to a malted meat product with \\
\hline Carbohydrates & mechanically separated poultry meat. \\
\hline Meat & Materials and methods. It is studied the technology of \\
\hline Sausages & sausages with adding to the composition of poultry meat \\
\hline Chitosan & mechanically, serum protein concentrate, soy protein \\
\hline Article history: & $\begin{array}{l}\text { developed protein-mineral carbohydrate supplement. } \\
\text { Determination of amino acid composition was conducted in }\end{array}$ \\
\hline $\begin{array}{l}\text { Received } \\
13.03 .2018\end{array}$ & $\begin{array}{l}\text { accordance with the method of ion exchange chromatography. } \\
\text { Results and discussion. Boiled sausage with a protein- }\end{array}$ \\
\hline $\begin{array}{l}\text { Received in revised } \\
\text { form } 09.05 .2018\end{array}$ & $\begin{array}{l}\text { mineral-hydrocarbon additive has higher consumer } \\
\text { properties compared to control samples. The moisture }\end{array}$ \\
\hline Accepted & content of minced meat which has been added to the chitosan, \\
\hline 29.06.2018 & $\begin{array}{l}\text { namely the soy protein, animal protein, serum protein, and } \\
\text { protein-mineral-hydrocarbon additi. increases by } 10-15 \% \text {, } \\
\text { which enables to increase the yield of the finished product }\end{array}$ \\
\hline & gical stages of production. \\
\hline $\begin{array}{l}\text { Corresponding } \\
\text { author: }\end{array}$ & $\begin{array}{l}\text { The addition of protein-mineral-hydrocarbon additi.in } \\
\text { the amount of } 10 \% \text { in hydrated state positively affects the } \\
\text { technological properties, it provides support for moisture, fat }\end{array}$ \\
\hline Oleg Halenko & during the heat treatment process, which is important when \\
\hline $\begin{array}{l}\text { E-mail: } \\
\text { galen } @ \text { i.ua }\end{array}$ & Cooked sausages has a balanced amino acid \\
\hline & $\begin{array}{l}\text { composition compared to control. In cooked sausages it is } \\
\text { observed higher levels of valine }(0.8 \%) \text {, lysine (by } 0.91 \%) \text {, }\end{array}$ \\
\hline & $\begin{array}{l}0.54 \% \text { ), aspartic acid (to } 0.65 \% \text { ) and glycine (at } 0.59 \% \text { )in } \\
\text { comparing with the control sample. }\end{array}$ \\
\hline & Conclusions. Chitosan when interacting with any animal \\
\hline & eases the moisture content of the finished product \\
\hline & $10-15 \%$. Boiled sausage with mechanically separated poultry \\
\hline & balanced composition, it has high consumer properties and \\
\hline DOI: & can be attributed to complete nutrition by content of essential \\
\hline $\begin{array}{l}10.24263 / 2310- \\
1008-2018-6-1-3\end{array}$ & amino acids. \\
\hline
\end{tabular}




\section{Introduction}

Due to the shortage of meat raw materials, proteins of plant and animal origin are widely used. These additives are used in the manufacture of all kinds of meat products, including delicacies, boiled smoked and smoked products. This tendency persists, which contributes to the expansion of the range of proposed additives, to improve their functional properties and to increase the level of safety, one of the criteria of which is the use (application) of genetically modified raw materials (Huang et al., 2011; Bou et al., 2009).

Proteins occupy an important place in the living organism, both in content in the cell and in the sense of life. Their share accounts for about $18 \%$ of human weight. Protein is an indispensable part of food and basic life. Soy and animal proteins allow you to make an equivalent replacement of non-sufficient precious raw materials (Richardson, 2002).

Meat from important food is the only source of valuable protein, which is an average of $18.0 \%$, which is a nutritional value of the first category. Depending on the species, the anatomical part of the animal, fattening, age, animal breeds, the protein content of the meat can vary from $11.0 \%$ to $22 \%$ (Peña et al., 2009; Hutchison et al., 2012). Among the proteins of the meat isolated connective tissue and muscle, which are divided into myofibrillary and sarcoplasmic. The nutritional and technological value of meat is higher, the more muscle tissue in it, the proteins of which belong to high-tech and high-tech.

Among vegetable proteins, soybean is most widely used. It is designed to reduce the cost of finished products and stabilize the formulation. Animal proteins have a diverse origin (collagen, milk, blood plasma, etc.), which causes a variety of technological processes and a wider range of applications than soya analogues.

The aim of the presented research is to improve the technology of producing cooked sausages, balanced by the mechanically separated poultry meat and protein-hydrocarbonmineral additive amino acid composition

\section{Materials and methods}

Materials for research were selected technology of cooked sausages with the addition of concentrate of serum protein (KSP), protein soy hydrated, animal protein, serum protein and protein-mineral-hydrocarbon additi. Chemical and physico-chemical methods of research were used in this work.

The articles of research are both new foods, selected to consideration in this work and industrial foods that is already used:

Methods, that allow to describe chemical composition, food and biological value, organoleptic, functionally-technological, structural and mechanical and economic indexes of research objects, were used in the process.

The sensory evaluation of quality of sausage products and ready-to-cook foods came true on a 5-ball scale.

A sensory estimation came true in a next sequence (Alison et al., 2011):

- $\quad$ original appearance - by a structure, by a picture on a cut, by even distribution of pieces of mushrooms in stuffing, by the type of shell;

- a color - by sight on the cut of intermediate product;

- a smell (aroma), taste and succulence - absence or presence of extraneous smell, aftertaste, degree of expressed of aroma of spicinesses and salinity determined;

- consistency - by pressing on good. 
The water absorption capacity of the products was determined using a stainless steel mesh cabinet, the bottom and walls of which were covered with filter paper to prevent product losses. The glass was moistened with water, which was allowed to stretch for 20 minutes and then weighed. After that, $3 \mathrm{~g}$ of the sample was introduced into the glass, kept for 20 minutes in such a way that the upper level of the test sample placed in the glass was below the liquid level by $8-10 \mathrm{~mm}$. After 20 minutes, the glass was removed from the water, held for 20 minutes for drainage and weighed (Weiss et al., 2010; Hoffmanm and Wiklund, 2006). Calculation of VAC (in \% to dry balance) was carried out according to the formula:

$$
x=\frac{m_{2}-m_{0}-m_{n}}{m_{n} \cdot(100-W)} \cdot 10^{4}
$$

where $\mathrm{m}_{2}$ - mass of the glass with the object under investigation after swelling in water, $\mathrm{g}$;

$\mathrm{m}_{0}$ - weight of a glass with a humidified sleeve, $\mathrm{g}$;

$\mathrm{m}_{\mathrm{n}}$ - weight of weight loss, $\mathrm{g}$;

$\mathrm{W}-$ mass fraction of moisture in the investigated object, $\mathrm{g}$.

Determination of amino acid composition was conducted in accordance with the method of ion exchange chromatography. Quality and quantitative determination of components consisted in dividing of them into separate components after the hydrolysis of proteins and determination of their quantitative estimation with the help of automatic analyzer of amino acids as T-339. Productions of firm "Mikrotechna", on polystyrene sulfonate ion exchange resins of "Ostion LJ ANB" in Li- citrate buffer one column mode (Peshuk and Galenko, 2011, 2014). The elutions of amino acids from a column conduct in turn by $\mathrm{Li}$ - by citrate buffers

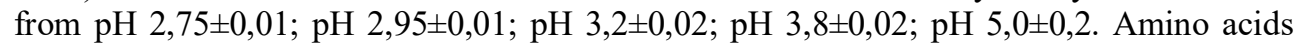
rectifying with the help of solution of ninhydrin on a running photometer at a length of waves by $560 \mathrm{HM}$. The results of detection was registered oneself by a variplotter on a paper in form the peaks of absorption of light of ninhydrin-positive substances in an eluate, that in number in direct ratio concentrations of this substance in solution. Correlation of solution of ninhydrin reagent and eluents is 1 to 2 ; temperature of thermostatic $\mathrm{T} 1=38,5{ }^{\circ} \mathrm{C} ; \mathrm{T}=65^{\circ} \mathrm{C}$. The prototype was diluted in Li-citrate buffer by $\mathrm{pH} 2,2 \pm 0,02$ and inflicted on a ion exchange column with the help of metering device. The quantitative estimation of хроматограм of pre-production model settles accounts in relation to standard mixture of amino acids of firm BioRaD. The amount of milligrams of every amino acid of $\mathrm{Ai}$ in the investigated solution calculates on a formula:

$$
A_{i}=\frac{M_{i} \times S_{i}}{S_{i}^{3}}
$$

where $A_{i}$ is mass part of $\mathrm{i}$-th amino acid, $\mathrm{mg} / 100 \mathrm{~g}$ of protein;

$M_{i}$ is molecular mass of $\mathrm{i}$-th amino acid;

$S_{i}$ is area of peak of $\mathrm{i}$-th amino acid on an aminogram from the investigated solution;

$S_{i}^{3}$ is an area of peak of $i$ amino acid on an aminogram from solution of standard mixture of amino acids, that accords to one micromole. 


\section{Results and discussion}

Consequently, it was selected as the main recipe components for the development of boiled sausages of balanced amino acid composition: poultry meat, mechanically separated poultry meat (MSPM), PMHA in the amount of $10 \%$, milk powder, eggs, and spices. We conducted a determination of the level of introduction of poultry meat, MSPM, PMHA in an experimental way, namely the method of selecting the optimal from the point of view of both sensory, and the nutritional and biological value of the developed meat product. Different combinations of supplements were introduced into the experimental formulations: soy protein, animal protein, hydrated whey protein, soy protein, animal protein + chitosan, serum protein + chitosan, PMHA + chitosan № 1 and № 2, SPC + chitosan, SPC, and PMHA. The developed formulations are presented in Table 1 (Peshuk and Galenko, 2011).

Table 1

Recipes of developed sausage wares

\begin{tabular}{|l|c|c|c|c|c|c|c|c|c|c|c|c|}
\hline & & & & & & & & & \\
\hline
\end{tabular}

The general mandatory requirements for the quality of finished products are: high sanitary and hygienic status, organoleptic parameters, the level of nutrient balance with reduced energy value. Therefore, the next stage of the research was devoted to the comparative assessment of physico-chemical, biological, functional and technological indicators of finished products in comparison with the control sample of cooked sausage made in accordance with the standard (Peshuk and Galenko, 2014). 
Proteins that are additionally introduced into the meat system affect the stabilizing effect of meat products, since meat products must have certain consumer properties: be juicy, tender, with distinct chewing ability and density.

MSPM has an elevated $\mathrm{pH}(6.8-7.0)$, which reduces the microbial stability of the raw material during storage. It is an inexpensive protein component of the recipes of semifinished, boiled and smoked sausages. The high content of calcium ions contributes to the deterioration of the functional and technological properties of MSM, which negatively affects the stability of albuminous fat emulsions in the formulation, which can lead to the appearance of soup-fatty stomachs. Therefore, when using poultry meat in the formulation at the same time it is necessary to make stabilizers and emulsifiers.

Considering the functional and technological properties of minced meat systems, important of which are $\mathrm{pH}$, water-binding ability (WBA), stability during storage, is of great importance when developing the technology of meat products. The quality of the waterbinding ability of meat depends on the quality of processing. The use of meat with a low WBA leads to significant losses of moisture and water-soluble proteins during heat treatment, which significantly reduces the quality of finished products.

Therefore, we have previously conducted a comparative analysis of functional and technical indicators of forages systems to evaluate the technological properties of developed sausage products (Figure 1).

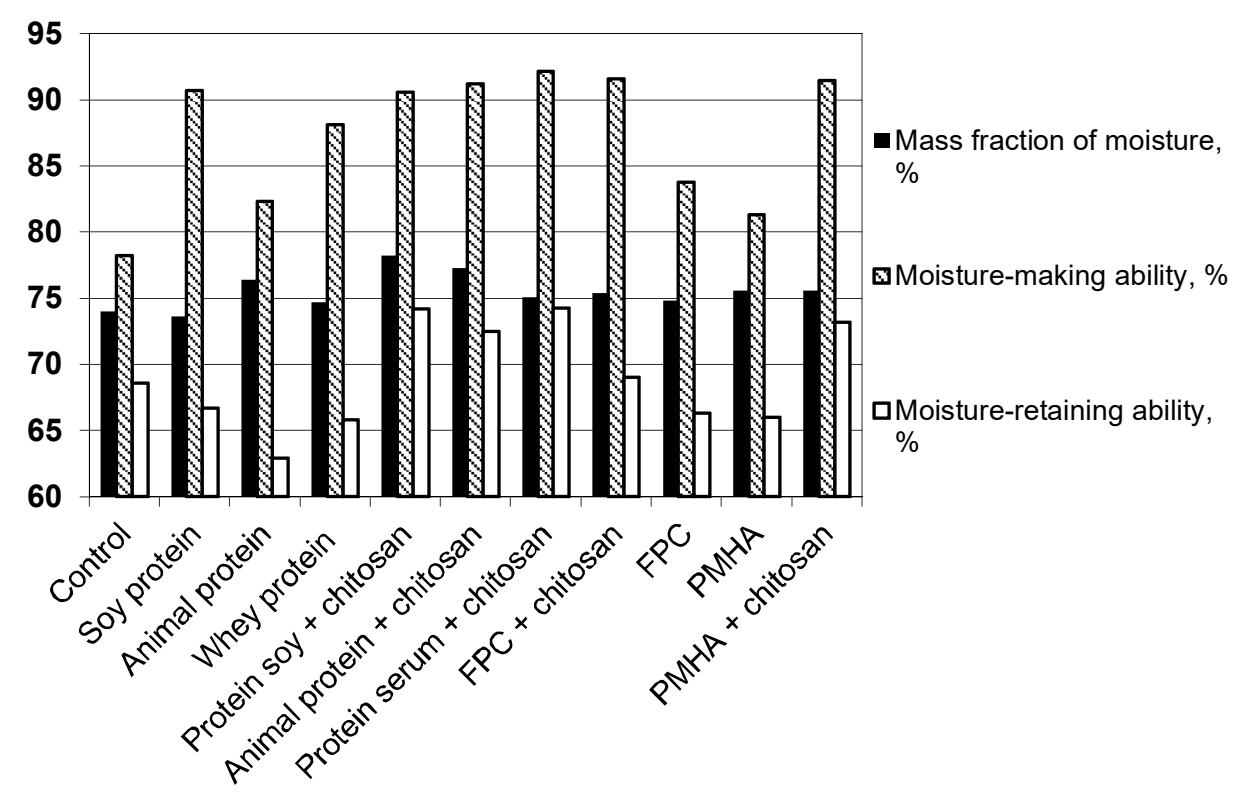

Figure 1. Functional and technical indicators of minced meat systems

From the conducted studies it was found that when the chitosan is added to the PMHA, the $\mathrm{pH}$ changes slightly in the alkaline side, which should increase the hydrophilicity of the meat proteins, which will increase the water-binding ability of the minced meat. Thus, the finished product will be more juicy and with better consumer characteristics. 
It has also been established that the moisture-retaining ability of the minced meat containing chitosan, in particular, the soya protein, animal protein, serum protein and PMHA values increases by $10-15 \%$, which enables to increase the yield of the finished product and plan the properties of the product after completion of technological stages of production (Hutchison et al., 2012).

The next stage of the research was the definition of functional and technological indicators of the finished product. In samples of sausage products with chitosan there is a slight change in $\mathrm{pH}$ in the alkaline side, which, as predicted, contributed to the increase of the hydrophilicity of meat proteins and, consequently, the increase of water-binding ability of minced meat, resulting in the finished product obtained more juicy (Table 2).

Table 2

Physico-chemical properties of cooked sausages

\begin{tabular}{|l|c|c|c|}
\hline \multirow{2}{*}{ Sample } & \multicolumn{3}{c|}{ Indicators } \\
\cline { 2 - 4 } & $\mathbf{p H}$ & $\begin{array}{c}\text { Mass fraction of moisture, } \\
\mathbf{\%}\end{array}$ & $\begin{array}{c}\text { WBA\%, to total } \\
\text { moisture }\end{array}$ \\
\hline Control & 7,05 & 73,97 & 95,46 \\
\hline Soy protein & 7,01 & 73,60 & 90,68 \\
\hline Animal protein & 7,01 & 76,41 & 82,30 \\
\hline Serum protein & 6,90 & 74,70 & 88,12 \\
\hline SPC & 6,92 & 74,80 & 88,76 \\
\hline PMHA & 6,91 & 75,60 & 91,30 \\
\hline Soy protein + chitosan & 6,95 & 74,20 & 90,57 \\
\hline $\begin{array}{l}\text { Animal protein + } \\
\text { chitosan }\end{array}$ & 6,86 & 77,30 & 91,20 \\
\hline $\begin{array}{l}\text { Whey protein + } \\
\text { chitosan }\end{array}$ & 6,85 & 75,10 & 92,17 \\
\hline SPC + hitosan & 6,93 & 75,40 & 91,57 \\
\hline PMHA + hitosan & 6,94 & 75,60 & 91,48 \\
\hline
\end{tabular}

The conducting of studies water-binding ability (WBA) has shown that the introduction of PMHA in the amount of $10 \%$ in hydrated state positively affects the technological properties of minerals to retain moisture and fat during the heat treatment, which is important when using the technology of cooked sausages. A slight increase in the output of prototype finished products was noted. There were no significant changes between the control and experimental samples of cooked sausages in terms of physico-chemical composition (Richardson, 2002).

Cooked sausages has a balanced amino acid composition compared to control. In cooked sausages it is observed higher levels of valine $(0.8 \%)$, lysine (by $0.91 \%)$, methionine (at $0.10 \%$ ), threonine (at $0.54 \%$ ), alanine (at $0.54 \%$ ), aspartic acid (to $0.65 \%$ ) and glycine (at $0.59 \%$ )in comparing with the control sample.

According to the content of essential amino acids ham meat guinea fowl close to egg protein, and according to the content of of amino acids as valine, isoleucine, leucine, lysine, alanine, arginine, aspartic acid, glycine, glutamic acid, tyrosine surpasses it.

This indicates that the cooked sausages and smoked guinea fowl meat have well balanced amino acid composition, it is characterized by high biological value and can be attributed to high-grade food for the content of essential amino acids (Peshuk and Galenko, 2014). 


\section{Conclusions}

1. It is reported that chitosan when interacting with any animal protein increases the moisture content of the finished product $10-15 \%$.

2. With the help of mathematical modeling method we optimized two recipes of guinea fowl meat products.

3. Using the method of mathematical modeling, we optimized the recipe of cooked sausages with protein-mineral-hydrocarbon additive.

4. The sausages of the balanced amino acid composition with mechanically separated poultry meat and protein-hydrocarbon-mineral additive, which received higher output of the finished product and the best consumer properties compared with the control sample, were investigated.

5. The calculations of economic efficiency provided the basis to recommend these elaborated ham for the introduction in meat processing enterprises of Ukraine, as the cost is $74 \mathrm{UAH} / \mathrm{kg}$.

\section{References}

1. Jochen Weiss, Monika Gibis, Valerie Schuh, Hanna Salminen, (2010), Advances in ingredient and processing systems for meat and meat products, Meat Science, 86(1), pp. 196213.

2. Hoffman L.C., Wiklund E., (2006), Game and venison - meat for the modern consumer, Meat Science, 74(1), pp. 197-208.

3. Alison J. McAfee, Emeir M. McSorley, Geraldine J. Cuskelly, Bruce W. Moss, Julie M.W. Wallace, Maxine P. Bonham, Anna M. Fearon, (2010), Red meat consumption: An overview of the risks and benefits, Meat Science, 84(1), pp. 1-13.

4. Huang S.C., Tsai Y.F., Chen C.M. (2011) Effects of wheat fiber, oat fiber on sensory and physico-chemical properties of Chinese-style sausages, Asian-Australian Journal of Animal Science, 24(6), pp. 875-880

5. Bou R., Codony R., Tres A., Decker E.A., Guardiola F. (2009), Dietary strategies to improve nutritional value, oxidative stability, and sensory properties of poultry products, Critical Review on Food Science and Nutrition, 49(9), pp. 800-822

6. Peshuk L., Galenko O. (2011), Gerodietic meat products technology enriched with calcium and phosphorus, Food and Environment Safety, X(4), pp. 18-23.

7. Richardson D.P. (2002), Functional Food and Health Claims, The world of Functional ingredients, 9, pp. 12-20.

8. Peshuk L., Galenko O. (2014), Use of collagenase in technology gerodietetic products , Journal of food and packing science, technique and technologies, 2(3), pp. 8-11.

9. Peshuk L., Galenko O. (2014), Rational use of the collagen, Ukrainian Journal of Food Science, 2(1), pp. 361-370.

10. Peña F., Bonvillani A., Freire B., Juárez M., Perea J., Gómez G. (2009), Effects of genotype and slaughter weight on the meat quality of Criollo Cordobes and Anglonubian kids produced under extensive feeding conditions, Meat Science, 83(3), pp. 417-422.

11. Hutchison C.L., Mulley R.C., Wiklund E., Flesch J.S. (2012), Effect of concentrate feeding on instrumental meat quality and sensory characteristics of fallow deer venison, Meat Science, 90(3), pp. 801-806. 